\title{
Abdalla Al-Nadeem, Pioneer of Patriotism and Civilization in the Modern Egyptian Thought
}

\author{
Hamed Hassan Hamzawy \\ Assiut University, \\ 71515 Assiut, Egypt, \\ hamzawyhamed967@yahoo.com
}

\begin{abstract}
Abdullah Al-Nadim (1842-1896) is one of the most important intellectual and political figures in modern Egyptian history. He played a major role in all significant stages of the Egypt nineteenth century. He was called "the orator of the revolution." He left his mark on various aspects of Arab social, political, and cultural life and awareness. So now it is very important to study and analyze his intellectual legacy, especially in contemporary circumstances, in which we see the rise of the new barbarism of various primitive religious Salafism. Abdullah Al-Nadim was one of the fine examples of the free intellectual. He committed to issues of society, national Idea, freedom, and progress. This study aims to trace the emergence and development of political, social, and literary ideas of Abdullah Al-Nadim. In their outcome, these ideas were the outcome of the Egyptian social, political, and national struggle against Ottoman despotism and its ruined remnants in the historical existence at that time. In his research and positions, critical and satirical ideas, precise clarity, depth, and loyalty to the truth and the nation's supreme interests are united. His creativity was a model for critical vision and mockery of the remnants of a collapsing world. He sought in all his works for alternatives to development and social progress, calling for modern civilization and freedom. His defense of women, their rights, and freedom was among the most dramatic at that time. Abdullah Al-Nadim sacrificed himself for these endeavors and goals. But at the same time, he revealed the possibility of synthesizing the poetic spirit and truth in theoretical and practical creativity. They are the issues and aspects that form the focus of this research.
\end{abstract}

Keywords: Abdalla Al-Nadeem, Al-Afaghani, civilization, Egypt, emancipation, nationalism, patriotism, urbanization

\section{Article history:}

The article was submitted on 05.01.2021

The article was accepted on 28.03.2021

(C) Hamzawy H.H., 2021

This work is licensed under a Creative Commons Attribution 4.0 International License https://creativecommons.org/licenses/by/4.0/ 
For citation: Hamzawy H.H. Abdalla Al-Nadeem, Pioneer of Patriotism and Civilization in the Modern Egyptian Thought. RUDN Journal of Philosophy. 2021;25(2):213-223. DOI: 10.22363/2313-2302-2021-25-2-213-223

\section{Introduction}

The idea of homeland and patriotism takes a large space of Arab thought, and it is attached to the idea of independence. Accordingly, the idea of patriotism generates within the souls. Man lives in his/her homeland, trying not to impose siege or invasion on his/her country.

Egyptian Abdalla Al-Nadeem best represents the patriotic character. He embraced the Urabi revolt's doctrines and internalized them from the beginning of the revolt and till its end. He worked on spreading its values, principles, and demands among the people of all denominations. He also believed in the principles of freedom and independence. He made urbanization and process an end to freedom and independence. No progress or urbanization can be achieved unless through freedom. Those who are under the constraint of slavery and colonialization will not experience progress or urbanization.

Abdalla Al-Nadeem was one of the Urabi revolt leaders to achieve the victory of right and freedom, uphold the values of citizenship and independence, and call for national unity. He delivered such enthusiastic speeches. He advocates the Urabi revolt all the way, during its strength and failure. This man had complete and constant belief in this revolution's values and others that seek freedom and independence and then urbanization and real strive towards what improves nations and communities' conditions. This is what the Urabi revolt sought, as Egypt was dominated by the British occupation that made the nation lose all its strength points. It also made the nation ready to accept colonialization and seizure, which came true in 1882 after the Urabi revolt's failure. Al-Nadeem expressed the progress and urbanization that he hopes for his country through his writings and speeches. The patriotic sense was apparent in his works. He called on people to abandon superstitions and stick to religious doctrines, thoughts, and contemporary sciences. $\mathrm{He}$ calls on them to stick to freedom and self-strengthen instead of the west, representing the most dangerous enemy, especially under Tribal chauvinisms, that disunites citizens of the same nation. He also calls for a revolution against the values of ignorance and the revival of the values of justice, knowledge, and freedom and an attempt to revive Islamic civilization's legacy. This is not strange for a man who was schooled at the hands of Al-Shiekh Jamal Al-Din Al-Afghani, who believes in the change that would uproot ignorance.

Thus, Al-Nadeem expressed the nation's concerns and citizens through the use of symbols many times to avoid conflict with statesmen of Egypt and the Ottman Empire in Turkey. The following is an account of Abdalla Al-Nadeems' life and his most important thoughts through which he found a way and a tool for progress, urbanization, and to lift the Egyptian community from underdevelopment and stagnation. 


\section{First: Abdalla Al-Nadeem: His Life, Thought and Works}

Abdalla Al-Nadeem is the writer, poet, revolutionary orator, and politician known as the Urabi revolt orator (1881). Al-Nadeem is Abdalla Ibn Musbah Ibn Ibrahim Al-Idrisi who was born in Alexandria in 1843 [1. P. 55]. He grew up in one of the poor neighborhoods. Once he grew up and was able to learn, his father sent him to school. He seemed clever that he was distinguished among his classmates in memorizing the Holy Quran. He understood what he learned at school before turning nine years old, which encouraged his father to continue Al-Nadeem's schooling in a finer school, the Al-Shiekh Ibrahim Basha mosque (Al-Anwar Mosque) in 1845 [2. P. 34]. However, he did bear with studying in this Mosque as he felt its desiccation and unsuccessful method of teaching and the poor quality of its books. He found within himself a will to something that he cannot walk away from (i.e., literature). He went out to the street of real life as it became like a university from which he learned and witnessed a lot. He drew on from it what would satisfy his literature hobbies, came to know about its folklife and heard the proverbs and stories from the poets of Rebab and anecdotes as he regularly visited forums and cafes [3. P. 6].

Al-Nadeem returned to Egypt, and when he heard of Jamal al-Din Al-Afghani, he frequently attended his sessions and admired his bold ideas. He also followed Al-Afghani's students' path and learned from him the freedom of research, criticism, and the audacity of defending the right. Thus, he became filled with the principles of nationalism and absorbed from him the principles of freedom [Ibid. P. 6-7].

Thus, it is clear that Al-Nadeem educated himself in a free and wide-ranging way that is not restricted to any curriculum, which made him encyclopedic in his thought. Thus, he wrote about religion, wisdom, history, and literature. He also resorted to political work and worked on expanding the national struggle base by turning the whole society into a national strike force. As a result, Al-Nadeem presented his thoughts through the press in an attempt to establish a public opinion that would stand against the injustice imposed upon the people inside or outside Egypt. Al-Afghani encouraged him to do so [Ibid. P. 7], and why not? Al-Afghani is a man of national political thought. Al-Nadeem drew the political work, the national struggle, and the revolutionary attitude from Al-Afghani.

The relationship between Al-Nadeem and lots of Egypt's literates became strong at that time. He drank from their sources and drew from their springs. On the day, he is a telegraph that receives and sends signals, while at night, he is a literate who accepts and imitates literature models [4. P. 206-207].

Al-Nadeem led a revolution of thought and an unarmed fight on the level of thought before a political one. The homeland was the battlefield, while the weapon was the pen and tongue. He tried to inspire motivation and achieve hops with his poems by focusing on education and its value and calling for the unity of the country and nation. Besides this intellectual fight, he tried to stir the national sentiment, especially during the Urabi Revolt events, which caused the political authorities to turn on him. 
Abdalla Al-Nadeem and the establishment of the Al-Tankit wal Tabkit newspaper. Before the dispute between Al-Nadeem and Riyad Basha, who was the Prime Minister at that time, grew, Al-Nadeem realized through his experience that Riyad would not let him carry on his reform path or even continue working at the association if its rhetorical forums criticize the regime, tyranny and the government's submission to the consuls of England and France who drained the blood of countries for their financial policy. When he began to sense the signs of the storm blowing at him and his association, he decided to issue a newspaper if he became banned from rhetoric that would convey his message to the people and contact him with his audience. He called this newspaper Al-Tankit wal Tabkit [5. P. 51]. He said, "I met Riyad Basha in Egypt, and he meant me harm, so I hyped him, and so did he. He was attracted by my speech that I could take permission from him to issue the Resmorsing newspaper. All I wanted was to criticize, and I wanted this newspaper to be my tongue if I leave the association so that I would have oral forums in all countries" [6. P. 55].

The first issue of the Al-Tankit wal Tabkit was issued in Al-Mahrousa and The New Age printing presses in Alexandria on Sunday the 6th, June 1881. This issue was a national comic literary newspaper that was published weekly in the form of a pamphlet. This newspaper's name was written in the upper part of the cover using Naskh script in large font. He decorated the title with a crescent drawing and a star as a symbol of national unity [3. P. 8].

Al-Nadeem discussed the topics and goal of this newspaper in the editorial of the first issue as he said, "This newspaper is a literary and disciplinary one that provides you with pearls of wisdom, literature, preachments, benefits, and comics in a simple language that the world would not despise nor would the ignorant need it to be clarified. It also depicts the incidents and events that would suit the souls and make them comfortable. Its approving and disapproving appearance tells you that its internal has familiar meaning. Its moral views alert you that beneath there is a beauty that loves and a charm that spirits request". He adds, "don't think that its comics is a mockery of us or of our works as they are only puffs and exhalations that go up to meet our present with our past" [Ibid. P. 8].

Al-Tankit wal Tabkit was the first to announce its adhering to the Army Organization, and it called for unity to get rid of slavery and colonialization and seek for abolishing submission to the English. Al-Nadeem announced his support for the rebellious movements of the army. The newspaper's role was to expose the flaws and corruption of Egyptian society in various respects in a comic sarcastic colloquial style that would help the public understand and alienate the intellectuals. The editor of this newspaper believes that this style would push the public to denounce downsides; it would also despoil the intellects' efforts to support enlightenment. Evidence for the success of this newspaper is that it succeeded in achieving its objectives and goals through its numbers, which were printed in thousands and implemented immediately after its issuance [7. P. 14-15]. During that period, the newspaper was that of the people, and it was the spark that ignited 
the fire of enthusiasm and the heat of patriotism in the souls of Egyptian people who seek independence.

Abdalla Al-Nadeem kept on believing in the values of the revolution even after its failure, and this is probably because the occupation put the screws to the countries, the wealth and money were depleted, and the people were worn out by the taxes. Al-Nadeem's soul was like that of a rebel who would not calm down as long as there is an error and stray, searching for right and independence, refusing injustice and tyranny, and seeking freedom without which the love of nations can not be achieved. Progress and urbanization can be achieved only under these nations with justice, freedom, and independence from any foreign dependency.

After the Urabi revolt's failure, Al-Nadeem was caught and exiled. After he returned back to Egypt, he resolved to resume his press struggle and established Al-Ustaz (Professor) newspaper. Its first issue appeared on September 23, 1892. It published the famous article If you were like us, you would have done what we did on January 17, 1893, in which he describes the easterners. This article is written in 26 pages to describe the condition of the East, West, and methods of colonialization and to condemn the Westerners' methods and the Easterners' negligence, then he invites them to circumvent the Khedive and ask him to maintain his rights, and this is what made Lord Cromer call upon Khedive Abbas to exile AlNadeem as part of his instigating policy. The issuing of the journal ceased on June 13, 1893, and Al-Nadeem was exiled for the second time [5. P. 73 - 79].

A gossip against Al-Nadeem reached the Ottoman Sultan. Therefore, he spent his life in difficulty in Astana. He did not live long as he became paralyzed. His illness got tough, and he passed away on October 10, 1896. His funeral was greatly celebrated with the presence of Mr. Jamal Al-Din Al-Afghani. Al-Nadeem died at the age of fifty-four. He did not have a long life; however, his life was wide and broad. He fed the people with his writings and provoked them with his thoughts. $\mathrm{He}$ also left us with what makes us laugh and what makes us cry [4. P. 243-245].

Ahmed Samir, in his translation of Al-Nadeem's life, says, "He has hundreds of big and small works, a divan of poetry composed of about three thousand lines, two novels, The Nation and The Arabs, literary letters only fourteen of which had reached the hands of Slavic compilers after much pursuit and hardship, Kan and Yakoun some which were printed in Professor newspaper and twenty-one books in different arts. Ahmed Samir adds that most of these books and works were stolen and burned. The Slavist says that the most important topics of Al-Nadeem are poetry, acting, literature, language, jurispendence, Sufism, exquisite and apparent. In most of these topics, he is a man of literary and mostly religious culture" [5. P. 102-103].

Among the greatest influences on his character, as he was Egypt's sole orator and first writer during the period of the Urabi Revolt, was his contact with Al-Za'aeem and the philosopher of the east, Mr. Gamal Al-Din Al-Afghani. Al-Nadeem contacted him in Cairo and Alexandria and received all his political and social principles in his regular school and meetings. Al-Nadeem is considered one 
of the loyal students of Al-Afghani, and his principles, if not the most distinguished one. Al-Afghani's student, Mohammed Abdo, was known for his reluctant implementation of his principles and his cowardice, while Mahmoud Samy Al-Baroudy was known for his betrayal. Al-Nadeem, on the other hand, was loyal to him until his very last breath [Ibid. P. 103-104].

In this way, Al-Nadeems' life was full of fight-or-fight responses from the successive governments in the country. Sometimes he hides within the country, sometimes outside it, and at other times he gets exiled with the knowledge of the government. He remained the first orator of the revolution and a motivator of the aspiring national sentiments to obtain freedom and independence. The following is a presentation of his most important ideas through which he tried to draw attention towards the methods of progress and urbanization and how to revive the Islamic legacy depending on the two ideas of the nation and unity and their close connection to progress and urbanization.

\section{Second: Al-Nadeem's social influences and their impact on establishing urbanization}

The country's development and urbanization are only possible through the main reforms that represent the general framework of the society in all its aspects. Al-Nadeem revealed the reasons behind the ignorance of our societies and tried to find solutions so that our nation can return to its old state when there was progress and prosperity. All the nations and civilizations that developed and progressed over the ladder of the nation followed such reforms.

Al-Nadeem's plan and policy against colonization were to start with the corruptions that spread among the society after colonization. Upon his return, he was surprised to find a tide of moral degradation and corruption in the countries. $\mathrm{He}$ found an unusual excessive and overt drinking of wine and the drinkers' irresponsibility towards the criticism of critics. The wine had spread greatly in towns and villages [1. P. 56]. Freedom was also misunderstood as a way to engage in pleasures and lusts, and religion and patriotism were disdained. Moreover, Al-Nadeem accused the Europeans of encouraging such stuff so that the east would fall, and its morals would degrade [8. P. 334].

This was the social life that Al-Nadeem found unpromising of progress or urbanization, but it threatens to relapse and ruin. These conditions are enough to bring down the greatest civilization and the strongest nations subjected to moral decline and religious disintegration. The people do not have a soul or a conscience, and the Islamic scholars are content with praying during that period. Their sciences are ones that do not involve anything that is new, and they solely stick to outdated sciences.

Al-Nadeem warns about the tide of blind imitation that invaded the Arab societies, especially the Egyptian society. We find him sometimes narrate stories or tales or tell jokes or blame so that people might wake up from their carelessness and move for the common good. 
He writes under the title The Evening of Obedience while sticking to the images of urbanization, ignoring its content and criticizing the people for failing and spending their money on useless stuff, as he states after narrating the story, "This is the condition of who does not refine while being young. He/she becomes a captive of his/her desires away from realizing the meanings, a dull, stupid coward but your sun has shined, the lights of knowledge and morals appeared, and the government became serious and persistent through which its men progressed, and you are delivered from the graves of darkness into the heaven of knowledge. A nation is looking for the reasons for its delay and what would develop it. It also marvels at the cowardice of its children and their efforts to execute knowledge with what they have composed of fun, unemployment, corruption of morals, and what they were doing from vices and nasty things during the evening of the extravagance [2. P. 83-85].

Thus, Al-Nadeem tries to reveal to us one of the most important reasons for backwardness, namely, inaction and defeat, where people turn away from morals and good returns and also from the circles of decency and knowledge. They would retreat to themselves while considering the study of the conditions of nations and the reasons behind their progress, not only this but also isolation from the state of the nation itself. Thus, people would live like useless empty palm trees and depend on what the ancestors left them. Al-Nadeem, in this story, likens the condition of the people in the Arab world as if they were dependent on the ancient Salafist civilization and did not try to offer any benefit to themselves or their successors. Their only concern is how to dispel and waste what their ancestors left behind. Al-Nadeem, in this story, is full of hope as he hopes for the government and the intelligent people of the nation in order to seek the urbanization and progress of homeland through enlightening the minds and providing them with decency and knowledge, purifying the hearts and souls with morals. He calls for denouncing backwardness and seeking knowledge as a reason for progress and urbanization.

Al-Nadeem, as an intellectual, open to foreign cultures, knows that morals and traditions are not the same in all societies, and he also knows that what suits one society does not have to suit another. He finds him saying, "It is customary in his morals that every nation and sect should be carried out on the morals and traditions that would inspire them when it is necessary to abide by the tradition and dress up with morals. Thus, the weak would imitate the strong, and the foolish would imitate the intelligent until this applies to all members of the nation or sect and appears as if it is an innate mountain inherited by the children. When it reaches this point, it would appear as if the morals and traditions of others are accepted. Even if we take two judges from two nations, each one of them will insist that his/her nation is right and would break up on repulsion and contradiction" [9. P. 11].

Al-Nadeem talks in a scientific way about the diversity of the traditions of every nation according to its circumstances, nature, and beliefs. Then, he shows how imitation is caused by social blending as the weak imitates the strong and the condemned imitates the governor. He also refers to the wave of imitation that swept 
over the Egyptians. Thus, they imitated the English in their appearance, styles of living, language, and inferiority. Then, he comments, "He who wants to imitate the traditions of another has to first look at the origin, benefits, and disadvantages of his traditions, then he at that of the other traditions. If he finds that his traditions are better and that they are important for the maintenance of the revolution, nationalism, nationality, language, or religion, then he has to keep his traditions, but if not and if he finds them disadvantageous to himself, his country and the social body or if he sees that these traditions won't make him abandon his religious belief, his sense of nationalism or national jealousness and if he abandons his tradition without considering the consequences, then he would surrender himself to a person who has abandoned his tradition without fighting, and it would be difficult for him to return to his nationality, patriotism or the characteristics of his nation after forgetting its traditions and morals" [8. P. 330; 1. P. 56].

Al-Nadeem lamented the nation for the presence of such heresies and superstitions and states, "Is there a country of ignorance and unfounded creeds like our country? A westerner would walk up early and open his eyes to his work, while the easterner would wake up to a silly warlock who would look into his future and deviate until he/she satisfies himself/herself with money. He asserts that countries cannot achieve urbanization and progress through cowardice and laziness but through effort and work" [3. P. 16]. He curses backwardness on the tongues of intelligent people and says, "if people continue to imitate what other individuals are doing without considering its benefit or prudence then sciences would be lost, traits would change, unity would decline, and all people would become asleep in the trend of imitation" [10. P. 13-15]. Hence, we realize that Al-Nadeem denounces blind imitation as it denies urbanization and proves backwardness.

This is how the social life was within the Egyptian society that Al-Nadeem described. He tried to unveil it and show that its traditions, customs, and morals were not those of religion or the world. We cannot be promoted to developed and urbanized nations through them, especially during the period of blind imitation of the European West and forgetting the return of the east its language and laws that the west denied.

\section{Woman in Al-Nadeem's Thought}

It is fair to mention that Al-Nadeem's credit in launching the first call for educating the woman on his newspapers after Master Rifa'a Al-Tahtawy composed his first instruction book to educate boys and girls. There is no doubt that this appeal had an influence in directing the thoughts of the citizens in a time where ignorance and myths became rampant and outdated traditions were adhered to and also at a time where time gave too little to the education of men. The promotion of the woman and her education is the basis of society's advancement and a cornerstone in building its glory because she is the mother of its children and the wife of its men. The woman is the one who offers her blood as food to the child since his 
childhood and her mind as food for his soul. Thus, she must be prepared with all the qualifications so that she can fully perform her duties [5. P. 280].

Al-Nadeem called for the education and upbringing of women during their childhood. He opened schools, and in the article Refining Girls is one of the Duties, he states, "The girl whom her father left her countless money and fortunes lost all her money and properties in a short time because of her ignorance and impoliteness. Her condition became that hideous, and she began to suffer after she used to live in glory and bliss. If she was refined with science, knowledge, familiarity with the art of writing and arithmetic, and an experience in trade and industry, she would have economized and observed her work" [11. P. 142].

Then he condemns the behaviors of women and says, "In summary, I see all our women impolite, and so they bring misfortunes to their husbands as they behave in a way that would lead to propositions". He also illustrates the benefits of educating girls and women in developing countries and without hiding from you that our little girls should be refined through progress, urbanism, the spread of knowledge, and the revival of nations. "For when they grow up in refinement, raise on knowledge and politeness, and when they become mothers of daughter and sons, they would work hard to refine their children as much as they could so that they may be labeled humans and promote to perfection. Besides, if women are refined and taught the laws of religion, they might maintain them more than we would do" [Ibid. P. 143-144].

We can summarize the efforts of Al-Nadeem on the issues that concern the woman in the following points:

1. Educating women. He called for the women education during the childhood, and he opened elementary schools to teach religion, history, domestic management, and childcare.

2. Social politeness. The necessary culture for the woman in the different stages of her life so that she can fulfill her social mission. He showed the difference between duties of the countryside and the city and forbidden the woman from the vices of the western city and its traditions that are inconsistent with the religious and moral values. He also called upon the woman to fight religious intolerance and upon the Islamic woman to bond her relationship with the Christian woman on a sound basis of good neighborliness and respect for one another.

3. Al-Marab journal. He wrote in Al-Ostaz journal on April 25, 1893 that he proceeded in issuing Al-Maraba to search for what concerns the woman in terms of understanding health matters, house management, childcare, and maternity, traditions, and morals.

4. Protecting the woman: he called for avoiding public prostitution and radicalization in wedding ceremonies or bringing home dancers, which would have a bad influence on the feelings and morals of the girls and women of the virtuous family. He also fought against the white slave trade [5. P. 280-282].

He also called for a school that would refine girls so that they would not pursue their mothers (unpolite) and to avoid the superstitious talk [12. P. 199]. This shows 
that Al-Nadeem recognized the importance of educating the woman as well as men to achieve and establish the foundations of urbanization and progress. Thus, he called for the importance of her education and an upbringing that is consistent with the religious morals and laws which are the basis of any progress or urbanization.

\title{
References
}

[1] Mahmoud Hemeida Mahmoud. Modern Arab Thought. Al-Hani' Publishing House.

[2] Ahmed Samir. Best Works of Al-Ndeem. $2^{\text {nd }}$ edition. Egypt, Hindiya Press, 1914. Part 1.

[3] Abdalla Al-Nadeem. Al-Tankit wal Tabkit. Introduction by Abdel Azim Ramadan. General Egyptian Book Organization; 1994.

[4] Ahmed Amin. Leaders of Reform in the Modern Age. Lebanon: Dar Al-Kitab Al-Arabi; 1948.

[5] Naguib Tawfik. Abdalla Al-Nadeem, the Orator of Urabi Revolt.

[6] Mohamed Ahmed Khalaf. Abdalla Al-Nadeem and his Political Memoirs. Cairo: The Anglo Egyptian Bookshop; 1956.

[7] Farouk Othman Abaza, et al. Abdalla Al-Nadeem: Readings and Research. Cairo: General Authority of Cultural Palaces; 1996.

[8] Ali Al-Hadidy. Abdalla Al-Nadeem, the Orator of Urabi Revolt. Cairo: Aalam Al-Arab.

[9] Abdalla Al-Nadeem: on Morals and Customs. Al-Ustaz. 1892 August 1; (24).

[10] Al-Tankit wal Tabkit. 1881 June 6; (1).

[11] Al-Tankit wal Tabkit. 1881 August 7; (9).

[12] Al-Tankit wal Tabkit. 1881 September 4; (12).

\section{About the author:}

Hamzawy Hamed Hassan - Assisstant Lecturer at the Faculty of Arts, Assiut University, Assiut, Egypt (e-mail: hamzawyhamed967@yahoo.com).

\section{Абдалла Аль-Надим, первооткрыватель патриотизма и цивилизации в современной египетской мысли}

\author{
Х.Х. Хамзави \\ Асьютский университет, \\ Egypt, 71515, Assiut, \\ hamzawyhamed967@yahoo.com
}

\begin{abstract}
Аннотация. Абдалла Аль-Надим (1842-1896) - один из ключевых интеллектуалов и политических деятелей в современной истории Египта. Он сыграл важную роль на всех значительных этапах развития Египта XIX века. Его называли «оратором революции», он оставил свой след в различных аспектах арабской социальной, политической и культурной жизни и сознания. Поэтому сейчас крайне важно изучать и анализировать его интеллектуальное наследие, особенно в современных условиях, когда мы наблюдаем подъем нового варварства различных примитивных салафитских течений. Абдалла Аль-Надим был одним из прекрасных примеров свободного интеллектуала.
\end{abstract}


Он занимался вопросами общества, национальной идеи, свободы и прогресса. Цель настоящей статьи - проследить возникновение и развитие политических, социальных и литературных идей Абдаллы Аль-Надима. Именно эти идеи стали результатом египетской социальной, политической и национальной борьбы против османской деспотии и ее пережитков, разрушенных в историческом бытии того времени. В его исследованиях и позициях соединились критические и сатирические идеи, точная ясность, глубина, верность истине и высшим интересам нации. Его творчество было образцом критического подхода и насмешки над остатками рушащегося мира. Во всех своих произведениях он искал альтернативы развитию и социальному прогрессу, призывая к современной цивилизации и свободе. Его защита женщин, их прав и свобод была одной из самых ярких в то время. Абдалла Аль-Надим пожертвовал собой ради этих начинаний и целей. Но в то же время он раскрыл возможность синтеза поэтического духа и истины в теоретическом и практическом творчестве. Именно эти вопросы и аспекты находятся в центре внимания данной статьи.

Ключевые слова: Абдалла Аль-Надим, Аль-Афагани, цивилизация, Египет, эмансипация, национализм, патриотизм, урбанизация

\section{История статьи:}

Статья поступила 05.01.2021

Статья принята к публикации 28.03.2021

Для цитирования: Hamzawy H.H. Abdalla Al-Nadeem, Pioneer of Patriotism and Civilization in the Modern Egyptian Thought // Вестник Российского университета дружбы народов. Серия: Философия. 2021. Т. 25. № 2. С. 213-223. DOI: 10.22363/2313-23022021-25-2-213-223

\section{Сведения об авторе:}

Хамзави Хамед Хассан - преподаватель, Асьютский университет, Асьют, Египет (e-mail: hamzawyhamed967@yahoo.com). 